\title{
DETERMINANTS OF PROFITABILITY OF SRI LANKAN
}

\section{COMMERCIAL BANKS}

\section{DY}

PNALIDHADMOIIKA BANUARA

TIHFSSSIS SUBBMIIEDEDTTO THEE UNIVHRSIITY Y OF SYRI

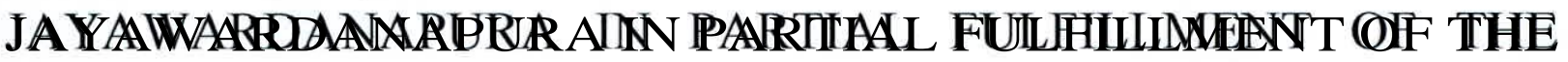
REQUUIRIENMENTSS FOOR THHE DEGIREE OF MASTER OF SCIENCE IN MANAGEMENT (IFINANCE)) 14.07.2015 
The work described in this thesis was carried out by me under the supervision of Professor Y.K. Weerakoon Banda and a report on this has not been submitted in whole or in part to any university or any other institution for another Degree/Diploma.

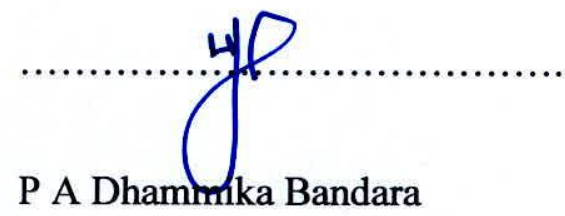


I certify that the above statement made by the candidate is true and that this thesis is suitable for submission to the University for the purpose of evaluation.

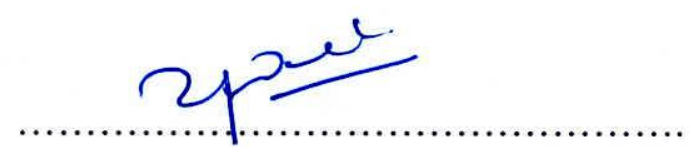

Professor Y.K. Weerakoon Banda

1.4) 7.72015

Date 
Chapter 5: Conclusion

5.1 Introduction

5.2 Conclusion

59

5.3 Suggestion for further research

60

References 
01. Variables and their hypothecated relationship

02. Descriptive statistics

03. Correlation Analysis

04. Regression result- ROAE model

05. Regression result- NIM model

06. Regression result - ROAA model 


\section{Acknowledgements}

I wish to place my heartfelt gratitude to Professor Y.K. Weerakoon Banda for his unstinted guidance, assistance and courage given to me throughout the preparation of the thesis. And also I fail in my duty if I do not mention the guidance provided by Dr. P.J.Kumarasinghe. 


\section{LIST OF ABBREVIATIONS}

LLP Loan Loss Provision

LDR Loan to Deposit Ratio

CIR Cost to Income Ratio

CAR Capital Adequacy Ratio

GDP Gross Domestic Production

MS Money Supply

INF Inflation

CBSL Central Bank of Sri Lanka

NIM Net Interest Margin

ROAA Return On Average Assets

ROAE Return On Average Equity 


\title{
Determinants of profitability of Sri Lanka Commercial Banks
}

By

\author{
P.A. Dhammika Bandara
}

\begin{abstract}
This paper investigates the magnitude of the impact of the bank specific determinants and macroeconomic indicators, on the profitability of Sri Lankan commercial banks. Financial data from eight commercial banks have been taken into in carrying out the study, representing both private sector and state sector. The period involved in the study is from 2001 to 2014 .

Three profitability measures namely return on average assets, return on average equity and net interest margin are included to make results more comprehensive. The independent variables employed are cost to income ratio, capital adequacy ratio, loan to deposit ratio, loan loss provision and size of the bank which are bank specific determinants. Other independent variables are year to year growth in gross domestic product, inflation and growth in money supply which cannot be controlled by the banks. Cross sectional regression analysis has been used to find out the independent variables which are statistically significant in explaining the three profitability measures. Statistical models have been designed to test the bank specific determinants separately as a first step and bank specific determinants under the influence of three macroeconomic indicators as the second step.
\end{abstract}

Cost to income ratio was found to be significant in explaining the profitability of the banks. Loan loss provision and growth of money supply have also been proved to be significant in explaining the profitability of banks. 


\section{CHAPTER 1}

\section{INTRODUCTION}

\subsection{Background}

Financial industry is the backbone of any country's economy. Sri Lanka being country with large number small and medium industries (SMIs) financial intermediation is more significant. With the liberalized economic policies, private sectors' involvement in the economy was made more prominent. Mostly the new breed of entrepreneurs found it difficult to raise capital on their own. Surge in the economy created a sound demand for lending .Consequent to the economic reforms in late nineteen seventies more players entered the financial industry hitherto dominated by the two state commercial banks.

As a result of the upward revision of interest rates on deposits more funds flowed into commercial banks, making them strengthening in lending. With the entry of new commercial banks including foreign banks, market share of dominant players were dwindling, affecting their degree of profitability.

Globally banking as an industry has been very competitive and innovative. As a result, the banking industry underwent tremendous technological advancement. Sri Lankan banking industry has been in the forefront among their Southeast Asian counterparts, in adopting these innovations. Performance of the banking industry got more prominent to face the growing level of competition. 
In the light of increased global trend of disintermediation, and its influence on the banking Industry in Sri Lanka, profitability has attracted the interest of academics, management of banks and regulators.

Regulator's role has also earned more prominence both locally and globally in light of negative shocks experienced by banks. The regulatory framework itself has introduced the Integrated Risk Approach assisting the sustainability of profitability of commercial banks. The directions given by the regulator will ensure to keep the pace of economy of the country at a sound level by making commercial banks more strengthened.

This paper is leveled at the investigation of determinants of profitability of commercial banks.

\subsection{Research Problem}

Profitability of the commercial banks is imperative for the very existence and to progress. Any commercial bank's strength will rest on the pillars of the deposits of the customers and funds of the shareholders or debenture holders. Raising money from all these sources will depend on the confidence of all stakeholders placed on the bank. Profit is the most basic economic indicator which will drive the investors.

Academics around the world have carried out plenty of studies on the determinants of profitability of commercial banks. Very little focus has been shed on the determinants of profitability and the magnitude of its impact in Sri Lanka. The available literature on the determinants of profitability of banks in Sri Lanka has only tested return on assets (ROA) in 
assessing the profitability. Current study aims to add two more profitability measures in addition to ROA, the one and only tested by another study, in view of deeper analysis of profitability. Profitability measures both return on average equity (ROAE) and net interest margin (NIM) are _t tested in the current study. Focus on NIM is vital in the banking industry, since it isolate the performance of its core business of accepting deposits and lending. Therefore the current study intends to expand the available knowledge on the financial industry in Sri Lanka particularly in the context of the core business of commercial banking.

In view of the above factors our object is to find out the determinants of the profitability of commercial banks which will fill the gap in the existing literature and improve the understanding of the determinants of bank profitability.

\subsection{Objective of the study}

Objective of the study is to measure the magnitude of the effect of bank specific and selected macroeconomic indicators on the profitability of commercial banks in Sri Lanka. Bank specific determinants comprise cost to income ratio, capital adequacy, loan to deposits ratio, loan loss provision and the size of the bank. Macroeconomic indicators included are inflation, growth in gross domestic production, money supply. 


\subsection{Significance of the study}

Commercial banks of Sri Lanka collectively account for $48.9 \%$ of financial assets of the financial industry. Out of the balance assets Central bank of Sri Lanka holds $12.1 \%$. The balance $39 \%$ is held jointly by all other financial institutions ${ }^{1}$. The magnitude of the Commercial banking sector involvement in the country's economy is clear with the Central Bank published data.

This investigation is aimed to appraise the applicability of profitability measure, net interest margin (NIM) in particular, which is vital to banking industry.

The outcome of the investigation may assist the investors, regulator, and bank management in making their decisions.

Virtual economic growth in the country is expected by a sound commercial banking sector which will augur well for the growth in gross domestic product of the country.

\subsection{Limitations}

Branches of twelve foreign banks have been excluded from the study. Local commercial banks have also been excluded due to non availability of data during the whole period under consideration.

\footnotetext{
${ }^{1}$ Central Bank of Sri Lanka Annual Report 2014 , page 178
} 